PERSPEKTIF, 8 (2) (2019): 53-58.

DOI: http://dx.doi.org/10.31289/perspektif.v8i2.2593

PERSPEKTIF

Available online http://ojs.uma.ac.id/index.php/perspektif

\title{
Ekspresi Verbal dan Nonverbal Customer CGV Cinemas Focal Point Medan terhadap Carry Bullying pada Instagram
}

\section{Verbal and Nonverbal Expressions of CGV Cinemas Customer Medan Focal Point Against Carry Bullying on Instagram}

\author{
Ruslan Hakiki Sambo*, Effiati Juliana Hasibuan \& Taufik Wal Hidayat \\ Program Studi Ilmu Komunikasi, Fakultas Ilmu Sosial dan Ilmu Politik \\ Universitas Medan Area, Indonesia
}

Diterima: Mei 2019; Disetujui: Juni 2019; Dipublish: Juli 2019

\begin{abstract}
Abstrak
Penindasan merupakan suatu kekerasan, ancaman atau paksaaan untuk menyalahgunakan atau mengintimidasi orang lain, bullying pada media sosial telah menjadi hiburan melalui gambar meme, dalam memberikan penelitian pendapat dan persepsi terhadap meme pada instagram.Penelitian ini menyangkut kasus korupsi mantan ketua partai Golongan Karya Setya Novanto, telah menimbulkan begitu banyak meme yang menyindir pejabat tersebut. Jenis penelitian ini adalah kualitatif, dengan pendekatan deskriptif. Sumber data penelitian ini di dapatkan melalui data primer dan data sekunder, dari teori -teori komunikasi verbal dan nonverbal dapat memberikan data carry bullying media sosial terutama pada instagram, penelitian ini di lakukan untuk mengetahui persepsi dari pengguna media sosial khusunya pada instagram.
\end{abstract}

Kata kunci : Ekspresi Verbal, Ekspresi Nonverbal, Persepsi, Gambar Meme

\begin{abstract}
Oppression is a violence, threat or force to abuse or intimidate others, bullying on social media has become entertainment through memes, in giving opinion research and perception of memes on Instagram. This research concerning the corruption case of the former chairman of thePartai Golongan Karya Setya Novanto, has caused so many memes that satirize the official. This type of research is qualitative, with a descriptive approach. The source of this research data obtained through primary data and secondary data, from the theories of verbal and nonverbal communication can provide carry media social media data especially on instagram, this research was conducted to find out the perception of social media users especially on instagram.
\end{abstract}

Keywords: Verbal Expression, Nonverbal Expression, Perception, Image Meme

How to Cite: Sambo, R.H. Hasibuan, E.J. \& Hidayat, T.W. (2019). Ekspresi Verbal dan Nonverbal Customer CGV Cinemas Focal Point Medan Terhadap Carry Bullying pada Instagram. PERSPEKTIF, 8 (2): 52-57.

${ }^{*}$ Corresponding author: ISSN 2085-0328 (Print)

E-mail: ruslanhakikisambo@gmail.com 


\section{PENDAHULUAN}

Penindasan atau bullying adalah penggunaan kekerasan, ancaman atau paksaaan untuk menyalahgunakan atau mengintimidasi orang lain. Hal tersebut meliputi pelecehan secara lisan atau ancaman, kekerasan fisik atau paksaan dan bisa diarahkan berulang pada korban tertentu atas dasar agama, kemampuan, gender, ras dan lain sebagainya.

Penindasan atau bullying adalah aktivitas yang dilakukan dengan tujuan memojokan orang lain dengan nada merendahkan, mengolok-olok hingga kekerasan fisik. Biasanya bullying terjadi bukan karena marah atau konflik yang tak terselesaikan, akan tetapi lebih merujuk pada rasa superioritas atau dengan kata lain untuk menunjukan bahwa pelaku bully yang paling kuat dan punya hak untuk merendahkan, menghina atau bertindak semena-mena pada orang lain.

Penindasan atau bullying tersebut dipakai untuk membuli para pejabat yang koruptor melalui sosial media yaitu instagram, dan bukan hanya para pejabat yang koruptor, melainkan para pesepak bola jika mengalami kegagalan, bullyingpada Lesbian, Gay, Bisexual, dan Transgender (LGBT) dan bullying pada sesuatu yang viral, kini saya akan membahas feedback ekspresi verbal dannonverbalnya kepada customer CGV Cinemas Focal Point Medan tentang carry bullying yang ada pada instagram yang biasanya disebut meme.

Fenomena carry bullying akhir-akhir ini netizen menggunakan dengan menyebarkan gambar meme yang sedang populer dimasyarakat saat ini. Meme dengan sangat cepat dapat menyebar melalui jaringan komunikasi dan secara tatap muka antar manusia. Meme adalah sebuah gambar, vidio, dan sebagainya yang disebarkan secara elektronik dari satu pengguna internet ke pengguna lainya. Penyebaran meme sangat cepat dilakukan melalui media sosial (Dwiana, 2015).

Kata-kata meme sudah lazim kita dengar beberapa tahun belakangan ini, meme bisa dalam bentuk gambar maupun video, dan menyebar sangat cepat di internet, meme bisa punah atau pun terus berkembangbiak hanya meme populerlah yang akan terus bertahan.Meme juga bersifat bebas karena tidak memiliki hak paten, oleh sebab itu siapa saja dapat membuat meme dalam bentuk yang berbeda-beda secara terus menerus (Natasha, 2016).

Berdasarkan latar belakang di atas dan carry bullying gambar meme yang dilakuan netizen menjadi trending topik di media sosial maka penulis tertarik untuk melakukan penelitian dengan judul: "Ekspresi Verbal dan Nonverbal Customer CGVCinemas Focal Point Medan terhadap Carry Bullyingpada Instagram (Studi Deskriptif Tentang Ekspresi Verbal dan Nonverbal Customer CGV Cinemas Focal Point Medan terhadap Carry Bullying yang Berfokus pada Gambar MemeSetya Novanto di Instagram)"

Pembahasan skripsi ini adalah berfokus pada meme yang mengenai Setya Novanto, Setya Novanto lahir pada 12 November 1955 di Bandung, Jawa Barat dari pasangan Sewondo Mangunratsongko dan Julia Maria Sulastri.

Maka dari itu peneliti merasa tertarik untuk melakukan penelitian terhadap Bagaimanakah ekspresi verbal dan nonverbal customer CGV Cinemas Focal Point Medan terhadap tindakan carry bullying gambar meme yang berfokus pada Setya Novanto di instagram.

Berdarasarkan latar belakang masalah yang diuraikan diatas, maka permasalahan dalam penelitian ini adalah untuk mengetahui bagaimana Bagaimanakah ekspresi verbal dan nonverbal customer CGV Cinemas Focal Point Medan terhadap tindakan carry bullying gambar meme yang berfokus pada Setya Novanto di Instagram.

\section{METODE PENELITIAN}

Penelitian yang berjudul "Bagaimanakah ekspresi verbal dan nonverbal customer CGV Cinemas Focal Point Medan terhadap tindakan carry bullying gambar meme yang berfokus pada Setya Novanto di instagram. ini menggunakan metode Penelitian Kualitatif menurut Sugiyono (2014) metode penelitian kualitatif adalah metode yang digunakan untuk meneliti obyek yang alamiah dimana peneliti sebagai instrument kunci, tehnik pengumpulan data secara triangulasi,analisis databersifat induktif dan hasil penelitian kualitatif lebih menekankan makna.

Dalam metode penelitian kualitatif penulis ikut berpartisipasi langsung ke 
lapangan. Peneliti melihat, mengamati dan mengumpulkan data melalui wawancara mendalam, observarsi serta dokumentasi berdasarkan fakta dilapangan melalui hasil tersebut peneliti dapat menuliskan laporan secara detail sehingga menghasilkan pemahaman secara spesifik.

Sutrisno Hadi dalam Sugiyono (2013) observasi merupakan suatu proses yang kompleks, suatu proses yang tersusun dari berbagai proses biologis dan psikhologis. Dua di atara yang terpenting adalah proses-proses pengamatan dan ingatan.

Menurut Esterberg dalam Sugiyono (2013) Wawancara merupakan pertemuan dua orang untuk bertukar informasi dan ide melalui Tanya jawab, sehinhgga dapat dikontruksikan makna dalam suatu topik tertentu.

Menurut Sugiyono (2013) dokumen merupakan catatan peristiwa yang sudah berlalu. Dokumen bisa berbentuk tulisan, gambar, atau karya-karya monumental dari seorang. Studi dokumen merupakan pelengkap dari penggunaan metode observasi dan wawancara dalam penelitian kualitatif..

Dalam teknik pengumpulan data, triangulasi diartikan sebagai teknik pengumpulan data yang bersifat menggabungkan data dan sumber data yang telah ada.

Analisis data dalam penelitian kualitatif, dilakukan pada saat pengumpulan data berlangsung, dan setelah selesai pengumpulan data dalam periode tertentu. Miles dan Huberman (1984), mengemukakan aktivitas dalam analisis data kualitatif dilakukan secara interaktif dan berlangsung secara terus menerus sampai tuntas, sehingga datanya jenuh. Aktivitas dalam analisis data meliputi: data reduction (reduksi data), data display (penyajian data), dan conclusion drawing (verification dan penarikan kesimpulan). (Sugiyono, 2007)

Moleong (2005) memaparkan tujuan uji (credibility) kredibilitas data yaitu untuk menilai kebenaran dari temuan penelitian kualitatif. Kredibilitas ditunjukkan ketika partisipan mengungkapkan bahwa transkrip penelitian memang benar-benar sebagai pengalaman dirinya sendiri. Dalam hal ini peneliti akan memberikan data yang telah ditranskripkan untuk dibaca ulang oleh partisipan. Kredibilitas menunjukkan kepercayaan terhadap data hasil penelitian kualitatif.

Menurut Moleong (2009) untuk menetapkan keabsahan data (trustworthiness) data diperlukan teknik pemeriksaan. Pelaksanaan teknik pemeriksaan didasarkan atas sejumlah criteria tertentu. Ada empat criteria yang digunakan, yaitu derajat kepercayaan (credibility), keteralihan (transferability), kebergantungan (dependability), dan kepastian (confirmability). Untuk menjaga keabsahan data, maka yang dipergunakan adalah teknik pengamatan lapangan dan teknik triangulasi data.

\section{HASIL DAN PEMBAHASAN \\ Ekspresi Verbal}

Menurut Ekspresi verbalnya dapat di lihat dari hasil penelitian, bagaimana informan meluapkan emosianal melalui kata-kata sangat setuju dengan adanya meme, akan tetapi disatu sisi meme dapat menimbulkan berita hoax yang dapat merugikan masyarakat dengan berbagai berita-berita yang hanya untuk mementingkan pribadi, akan tetapi dibalik itu memejuga bisa memberikan suara rakyat melalui gambar yang sudah di edit sesuai apa yang ingin di sampaikan, semuanya mempunyai dampak baik dan buruknya, tergantung cara masyarakan menggunakan meme tersebut yang ada pada instagram.

Kasus dari Setya Novanto adalah kasus yang paling dibenci masyarakat, jadi maka dari itu masyarakat menyindirnya melalui meme, meluapkan ekspresi emosional melalui meme yang ada pada instagram untuk membuli koruptor yang sudah banyak memakan uang rakyat dengan melontarkan kata-kata yang sangat menyinggung, ini adalah beberapa kata informan yang terlihat begitu jelas emosional ketika melontarkan kata-katanya.

Ekspresi verbal costumer CGV Cinemas Focal Point Medan ialah mereka sangat antusias dengan memberikan pendapat jika meme tidak ada maka Setya Novanto tidak akan di ketahui persis kasus yang menimpanya oleh kebanyakan masyarakat karena masyarakan di era sekarang lebih banyak menghabiskan waktunya di sosial media dari pada menonton acara berita di televisi ataupun membanca koran untuk mengetahui kasus-kasus yang lagi viral di Indonesia, dan informan sangat setuju dengan keberadaan 
meme yang ada pada instagram karena sangat menyuarakan suara rakyat.

Buli adalah suatu hal yang sangat tidak disukai kebanyakan orang, akan tetapi jika bulinya melalui sosial media dan menyindir atau membuli orang yang bersalah melanggar hukum tetapi hukumnya berpihak, maka buli media online ini sangat berpengaruh, yang sangat di antusias dari cyberbullying berita hoax, informan setuju dengan meme pada instagram akan tetapi rasa tidak setujunya juga ada dengan penyebaran berita bohong, untuk meme pada Setya Novanto yang begitu viral adalah hal yang paling disukai dari kebanyakan carry meme.

Bebicara dan Menulis yang dilakukan Informan, yaitu pada peryataan-pernyataan customer CGV Cinemas terhadap carry bullying yang ada pada instagram melalui ekspresi verbal mereka menyatakan bahwa sebagian besar dari informan setuju bahwa adanya meme untuk menyindir hukum di Indonesia ini, akan tetapi tidak untuk menyebarkan informasi hoax apalagi sindiran untuk kasus yang hoax, ungkapan customer CGV Cinemas melalui kata- kata yang di lontarkan dapat menyimpulkan agar pengguna meme dibatasi usia dan penyalah gunaan meme untuk berita yang tidak benar segera di cari solusi agar tidak merugikan suatu pihak yang tersinggung.

Mendengar dan Membaca Informan, dalam teori ini menjelaskan bahwa mendengar dan mendengarkan berbeda, mendengar hanya sekedar mendengar suatu kata dan mendengarkan lebih mengamati kata, maka dari cara customer mendengar suatu kasus yang menimpa Setya Novanto customer tidak terlalu mengamati kasusnya melainkan lebih mengetahui meme-nya kebanding kasusnya, maka setelah mengetahi meme untuk sindiran terhadap Setya Novanto customer lebih mendengarkan lagi untuk kasus yang menimpa Setya Novanto.

\section{Ekspresi Non Verbal Informan}

Ketika sesi tanya jawab, informan memberikan ekspresi nonverbal dengan wajah yang gembira yang menandakan informan sangat menyukai pembahasan tentang penelitian ini, informan yang sangat sering menggunakan instagram, dari ekspresiwajah yang saya dapat sangatlah setuju dengan keberadaan meme yang ada pada instagram, cara informan memainkan jari telunjuknya dengan hal itu informan memberikan hal positif pada meme lebih besar yang dirasakan dibandingkan hal yang negatif.

Ekspresi nonverbal yang saya dapat ketika sesi tanya jawab ialah dari ekpresi yang dia keluarkan dengan ekspresi yang sangat kaku, dari ekspresi informan ini setuju dengan keberadaan meme akan tetapi informan terlihat kaku ketika dalam sesi tanya jawab menimbulkan komunikasi bahwa setujunya masih dalam hal keraguan, dari gerak jari telunjuk yang dimainkan di dekat saku celana, akan tetapi dari jawaban yang informan berikan saya dapat menyimpulkan bahwa informan sangat jarang sekali mendapatkan tanya jawab dari orang-orang disekitar melainkan orang-orang terdekatnya.

Ekspresi nonverbal dari informan ialah dari raut wajahnya yang sangat elegant saya dapat menyimpulkan informan adalah orang yang sangat tegas dalam menyimpulkan hal apapun, informan mengatakan setuju dengan keberadaan meme begitu juga dengan ekspresi wajahnya, dengan cara letak tangan yang ada di atas meja dan ekspresi wajah yang sedikit tersenyum seolah berkomunikasi bahwasanya dia adalah bukan orang yang sembarangan jika memberi pernilaian terhadap apapun.

Ekspresi nonverbal yang terlihat dari informan ialah keakrapan yang mudah dapat dari ekspresi wajahnya, dalam sesi tanya jawab dia memberikan jawaban seolah meme pada instagram itu adalah bagian dari hidupnya dengan jawabannya yang sangat setuju akan tetapi dia seolah berkata walaupun setuju tapi meme dibatasi untuk pengguna dari nonverbal informan menaikkan tangannya dan menurunkan dengan nonverbal besar dan kecil seolah informan menandakan usia.

Kasus Setya Novanto memang sempat begitu viral di Indonesia, begitu pula meme terhadap Setya Novanto semakin meluas dan bertebaran dan menimbulkan ekspresi terhiburnya masyarakat terhadap meme tersebut sehingga meme Setya Novanto lebih menarik untuk di teliti melalui ekspresi verbal, ekspresi nonverbal mempunyai 6 jenis yang diteliti dari informan.

Sentuhan yang terjadi pada informan, yaitu ketika customer CGV Cinemas beberapa di antaranya memainkan jari telunjuknya menyentuh saku celananya dan 
memainkan kelima jarinya menyentuh meja yang dapat menimbulkan komunikasi nonverbal bahwa customer lagi berfikir untuk melontarkan jawaban dari pertanyaanpertanyaan tentang cyberbullying gambar meme terhadap kasus Setya Novanto yang ada pada instargam.

Kronemixatau penggunaan waktu yang di pakai informan, ketika customer CGV Cinemas melontarkan jawaban, customer juga mempunyai durasi ketika bertanya dan menimbukan ekspresi nonverbal, customer bisa saja tidak konsisten dengan jawaban atau juga sedang berfikir untuk memberikan jawaban yang terbaik, dan beberapa customer juga mempunyai durasi yang singkat dan dapat siartikan bahwa customer seorang yang percaya diri dalam jawabannya.

Gerakan tubuh informan, yaitu pada kontak mata, ekspresi wajah, isyarat dan sikap tubuh adalah bagian dari nonverbal gerakan tubuh, kontak mata dan ekspresi wajah customer dapat menyimpulkan bahwa customer adalah seorang yang tidak sembarangan memberikan jawaban, dari bentuk kontak mata dan ekspresi wajah sebagaian besar customer senang akan adanya meme pada instagram karena dapat menghibur pengguna instagram.

Proxemikatau jarak informan, pada teori ini tidak begitu menggambar pada customer karena teori ini membahas tentang jarak, ruang dan lokasi, mungkin dapat disimpulkan komunikasi ini menjelaskan bahwa customer berkomunikasi nonverbal melalui jarak antara informan dan komunikator tidak begitu memberikan komunikasi hanya dapat menjelaskan bahwa customer boleh-boleh saja jika ingin ditanyakan tentangcyberbullying gambarmeme pada instagram.

Vocalik atau cara berbicara informan, yaitu Customer CGV Cinemas memberikan cara berbicara yang kesannya ingin akrab dengan jawabannya dan sebagian customer pemalu akan tetapi tegas dengan jawaban yang diberi.

Lingkungan tempat informan, pada teori lingkungan ialah nonverbal suatu lingkungan, ruang, warna dan lokasi yang menimbulkan komunikasi, teori ini memberikan suatu bahwa customer datang di lokasi penelitian di CGV Cinemas ialah untuk menonton film dan warna baju yang dikenakan memberikan nonverbal bahwa customer seorang yang elegant dan tidak sembarangan.

\section{SIMPULAN}

Informan mempunyai cara tesendiri dalam menilai meme yang ada pada instagram yang berfokus pada Setya Novanto, dalam verbal dan nonverbal yang informan berikan ketika sesi penelitian ialah cara mereka meluapkan emosional mereka, kegembiraan dan hiburan sudah bagian dari meme yang informan lihat dari instagram, dan juga meme kasus Setya Novanto adalah bagian dari hiburan untuk informan.

Informan yang aktif di sosial media dan juga menanggapi keras akan meme Setya Novanto, walaupun dari cara yang kaku, terlihat dari verbal dan nonverbalnya bahwasanya informal setuju dengan meme yang ada pada instagram akan tetapi tidak terlalu memperdulikan.

Ekspresi verbal dan nonverbal dari informan bahwa informan sangat suka dengan pembahasan yang mengenai meme pada Setya Novanto yang ada pada instagram, karena menurut dari jawaban informan bahwa hal positifnya lebih besar dari hal negatifnya, masyarakat yang dulu hanya bisa menerima apapun hasil dari hukum yang tidak seimbang, kini masyarakat dapat menyuarakan suaranya melalui sindiran meme terutama pada instagram.

Beberapa hal menarik dari informan adalah dari pengalamannya melalui pekerjaan informan sangat aktif di media sosial dan menunjukkan banyak nonverbal dari gerak tangannya, dari pertanyaan yang diberikan dari ekpresi wajah informan I, II, III, dan IVdapat memberikan kontak mata yang sangat menyakinkan jawaban yang diberikan.

\section{DAFTAR PUSTAKA}

Adityawarman, (2000), Penelitian Dalam Suatu Metode: Bandung

Widiasti, A.R, (2014). Komunikasi Interpersonal Seniman Graffiti di Kota Bandung.

Gaspersz, V. (2013). Total Quality Management. Jakarta: PT. Gramedia Pustaka.

Kriyanto, R. (2006). Teknik Praktis Riset. Jakarta: Kencana.

Laksana, F. (2008). Manajemen Pemasaran, 1st ed. Yogyakarta: Graha Ilmu.

Nasrullah, R. (2014). Teori dan Riset Media Siber (Cybermedia). Jakarta: Kencana Prenadamedia Group. 
Ruslan Hakiki Sambo, Effiati Juliana Hasibuan \& Taufik Wal Hidayat, Ekspresi Verbal dan Nonverbal

Nasrullah, R. (2015). Media Sosial. Bandung: PT Remaja Rosdakarya

Nawawi, H. (2001). Metode Penelitian Bidang Sosial. Yogyakarta: Gajah Mada University Press.

Sendjaja, S.D. (2004), Pengantar Ilmu Komunikasi, Jakarta: Universitas
Sugiyono, (2008), Metode Penelitian Pendidikan. Bandung: CV. Alfabeta.

Suharto, (2010), Ilmu Komunikasi Verbal dan Nonverbal, Bandunng: Gajah Mada University Press. 